\title{
10
}

\section{Jurisdiction and Choice of Law in International Antitrust Law - A US Perspective}

\author{
HANNAH L BUXBAUM* AND RALF MICHAELS**
}

\section{Introduction}

\section{A. The Value of a US Perspective}

This essay provides a US perspective on conflict-of-laws ${ }^{1}$ issues in the area of antitrust law, focusing on jurisdiction and choice of law. ${ }^{2}$ Such a perspective should be of interest to Europeans for a variety of reasons. First, modern substantive antitrust law has a longer history in the United States than in Europe, and much of contemporary European law was developed with the US experience in mind (which is not to say that the model was always followed). Second, the United States has long experience with the conflict-of-laws questions concerning antitrust law; here again, Europe has learned from the US experience (especially with the effects doctrine) without necessarily copying it. Third, the United States and Europe are the world's most important antitrust enforcers, so combined they play a predominant role in global antitrust governance.

A further reason, however, may be the most important one. The European interest in private international law rules for antitrust comes at a time when both of those fields are in flux in Europe. Europe is currently experiencing a conflict-of-laws revolution, moving from a traditional focus on two-party relations grounded firmly in private law toward a more regulatory understanding. ${ }^{3}$ At the same time, antitrust law in the European Union is being changed in fundamental ways, with the move to decentralised enforcement in the

* Professor at the Indiana University Maurer School of Law.

** Professor at the Duke University School of Law.

${ }^{1}$ In this chapter, we use the terms conflict of laws and private international law interchangeably.

${ }^{2}$ Recognition and enforcement of judgments, the third pillar of private international law, is covered in this book by C Kessedjian.

3 See, for this shift more generally, R Michaels, 'The New European Choice-of-Law Revolution' (2008) 82 Tulane Law Review 1607 (English version of 'Die neue europäische IPR-Revolution: Regulierung, Europäisierung, Mediatisierung' in D Baetge, J von Hein and M von Hinden (eds), Die richtige Ordnung. Festschrift für Jan Kropholler zum 70. Geburtstag (Tübingen, Mohr Siebeck, 2008) $151 \mathrm{ff}$ ); see also H Muir Watt, 'Reshaping Private International Law in a Changing World' (Guest editorial, 2008) available at http://conflictoflaws.net/2008/ guest-editorial-muir-watt-on-reshaping-private-international-law-in-a-changing-world/. 
Member States and to increased private enforcement. In two particular respects, the US experience speaks to these shifts in orientation.

First, antitrust law is predominantly regulatory law. This is true even for private damages claims, as one of the major purposes of such claims remains regulatory. ${ }^{4}$ This characteristic fits uncomfortably with private international law as it has been traditionally understood in Europe - focused only on private interests. ${ }^{5}$ As European private international law adapts to a more regulatory function, the US perspective can provide some guidance. True, conflict of laws in the United States is also subject to what has been called a 'public law taboo', whereby foreign public law cannot normally be applied by a US court. ${ }^{6}$ However, the distinction between private and public law is far less important in the United States than in Europe, ${ }^{7}$ and it matters less in the conflict of laws, too. Thus, in antitrust, the question whether domestic law should be applied or not is answered in explicit acknowledgment of the regulatory interests embodied in that law. Similarly, foreign regulatory interests are acknowledged as a relevant criterion in addressing the conflict of laws, even if the response to overwhelming foreign interest is typically dismissal of a claim rather than application of the foreign law. ${ }^{8}$

Second, insofar as antitrust law affects markets, international antitrust litigation often affects a great number of plaintiffs - such as consumers and distributors - and, at least in the case of anti-competitive agreements such as cartels, a multitude of defendants. This does not fit well with the two-party relation that characterises European conflict-of-laws thinking and doctrine, both in jurisdiction ${ }^{9}$ and in choice of law. The two-party focus is especially inadequate with regard to any attempts to concentrate litigation: by pooling plaintiffs and/or defendants, and by making sure that the same law applies to all aspects of the litigation. Here again, US law may provide valuable lessons, particularly on the basis of the US experience with class actions.

At the risk of over-generalising, it can be said that US law puts into effect, quite consistently, a market-focused conception of antitrust law. This market-focused conception extends to questions of private international law, which is characterised by quite universal application of an effects doctrine. The conception supports a framework that appears successful in addressing diverse national markets as long as they remain separable - but that fails in addressing the most difficult challenge that international antitrust law faces today, namely global markets.

\footnotetext{
${ }^{4}$ See, for the United States, HL Buxbaum, 'Private Enforcement of Competition Law in the United States: Of Optimal Deterrence and Social Costs' in J Basedow (ed), Private Enforcement of EC Competition Law (Alphen aan de Rijn, Kluwer, 2007) $41 \mathrm{ff}$. In Europe, regulation is viewed as secondary vis-a-vis compensation in the 'Damages actions for breach of the EC antitrust rules' (White Paper) COM (2008) 165 final, 2 April 2008, 3. See also European Parliament resolution of 26 March 2009 on the White Paper on damages actions, P6_TA(2009)0187 No 4 ('collective redress ... is an important deterrent'); Opinion of the European Economic and Social Committee on the White paper on damages actions for breach of the EC antitrust rules [2009] OJ C228/40, 40 No 1.2 ('an improvement of the rules for private enforcement will in future have benefits in terms of deterring potential breaches').

${ }^{5} \mathrm{~J}$ Basedow, 'Jurisdiction and Choice of Law in the Private Enforcement of EC Antitrust Law' in Basedow, Private Enforcement of EC Competition Law (Alphen aan de Rijn, Kluwer, 2007) 229, 236-37.

${ }^{6}$ AF Lowenfeld, International Litigation and the Quest for Reasonableness (Oxford, Clarendon Press, 1996) 4-5; WS Dodge, 'Breaking the Public Law Taboo' (2002) 43 Harvard International Law Journal (Harvard ILJ) 161.

7 R Michaels and N Jansen, 'Private Law Beyond the State? Europeanization, Globalization, Privatization' (2006) 54 American Journal of Comparative Law 843.

8 See III.A.iv below.

${ }^{9} \mathrm{H}$ Muir Watt, 'Brussels I and Aggregate Litigation or the Case for Redesigning the Common Judicial Area in Order to Respond to Changing Dynamics, Functions and Structures in Contemporary Adjudication and Litigation' (2010) Praxis des Internationalen Privat- und Prozessrechts 111.
} 


\section{B. Doctrinal Matters}

While the US perspective can be a valuable one, the comparative insights that can be drawn from it are limited, at least prima facie, by certain doctrinal matters. In the United States, most conflict-of-laws issues concerning antitrust law are discussed not as choice-of-law problems, as they are in the Rome II Regulation, but instead as matters of jurisdiction - in particular, subject-matter jurisdiction (or, according to others, legislative jurisdiction). This essay is not the right place to demonstrate at length why this approach is really a (somewhat concealed) choice-of-law approach. However, an introduction into the basic structures of US law in this regard appears necessary.

Federal antitrust law is applied (almost) exclusively by federal courts. These are courts of limited subject-matter jurisdiction (personal jurisdiction is a different matter entirely). Two bases of their jurisdiction are especially important for international antitrust law. The first is federal question jurisdiction. Pursuant to 28 USC section 1331, 'district courts shall have original jurisdiction of all civil actions arising under the Constitution, laws, or treaties of the United States'. This means that federal courts have jurisdiction over antitrust claims whenever, and to the extent that, US antitrust law applies to those claims. Because the territorial limits of the scope of US antitrust law also determine the federal courts' jurisdiction on this basis, the questions of subject-matter jurisdiction and choice of law are easily conflated in the US system.

On one view, a conclusion that US antitrust law does not apply is interpreted as the failure to state a claim, meaning that the facts alleged by the plaintiff do not support a claim under US antitrust law (because, under a conflict-of-laws analysis, US antitrust law would not be applicable). ${ }^{10}$ This view avoids mingling questions of choice of law with those of jurisdiction. The majority view, however, treats these questions under the rubric of subjectmatter jurisdiction. Under this approach, the limits to the territorial scope of US antitrust laws automatically define the limits of judicial jurisdiction. This means that the choice-oflaw question must be answered already at the jurisdictional stage, and the fact that questions of applicable law are treated as a matter of procedure in this sense creates certain doctrinal problems.

It is important to note that federal courts enjoy alternative bases for subject-matter jurisdiction; thus, the application of foreign antitrust law will not necessarily be ruled out on jurisdictional grounds. One important basis is diversity jurisdiction. Federal courts have original jurisdiction over claims when diversity of citizenship exists - in other words, if plaintiffs and defendants are from different States or nations. Usually, complete diversity is required: none of the plaintiffs may have the same domicile as one of the defendants. The Class Action Fairness Act of 2005 relaxed this requirement for class actions above a certain claim threshold, however. ${ }^{11}$ In such cases minimal diversity is sufficient, which requires only that one plaintiff and one defendant are from different States or countries. ${ }^{12}$ Another alternative basis is supplemental jurisdiction. Pursuant to 28 USC section 1367, federal

${ }^{10}$ United Phosphorus Ltd v Angus Chemical Co 322 F 3d 942, 958 (7th Cir 2003) (J Wood, dissenting). On the various meanings of jurisdiction, see also HM Wasserman, 'Jurisdiction and Merits' (2005) 80 Washington Law Review 643.

1128 USC s 1332(d)(2), introduced by the Class Action Fairness Act, vests the federal district courts with original jurisdiction over certain class-action claims that exceed $\$ 5,000,000$.

12 ibid. 
courts have the authority to hear additional claims substantially related to a claim over which they have original jurisdiction, even if they would not have subject-matter jurisdiction to hear those additional claims independently.

\section{Personal Jurisdiction}

Functionally, the jurisdictional issues addressed by the Brussels I Regulation are dealt with in two different contexts within the US system: first, the law relating to personal jurisdiction (both statutory law and constitutional law); and second, the doctrine of forum non conveniens, which permits courts to decline jurisdiction when a more appropriate forum is available elsewhere.

\section{A. Personal Jurisdiction}

The jurisdiction of a US federal court over a particular defendant rests on two separate elements: statutory authority to exercise jurisdiction, and a determination that the exercise of jurisdiction will not violate the defendant's constitutional right to due process. ${ }^{13}$ In federal antitrust claims, the statutory authority resides in the venue provisions of the antitrust laws. ${ }^{14}$ With regard to the due process limitation, antitrust litigation often raises no special problems. This is so, in particular, in cases in which general jurisdiction can be established, based on the defendant (or its alter ego) doing business in the United States. ${ }^{15}$ In cases resting on specific jurisdiction, however, certain aspects are worth highlighting.

\section{i. Targeting}

The most important jurisdictional basis in the Brussels I scheme is Article 5(3), which assigns jurisdiction to the courts of the place of the injury. Under US law, the place of injury does not, in and of itself, confer jurisdiction, and Article 5(3), without limitations, would violate the Constitution. ${ }^{16}$ However, an important basis for specific jurisdiction over antitrust actions emerges from US Supreme Court case-law originally developed in the defamation context ${ }^{17}$ but since expanded more broadly to other intentional torts. If a defendant has targeted the forum in question with intentionally tortious conduct, a court in that forum may exercise specific jurisdiction over that defendant in a resulting claim.

${ }^{13}$ For comparison of this two-stage process with European law, see A Nuyts, 'Due Process and Fair Trial: Jurisdiction in the United States and in Europe Compared' in A Nuyts and N Watté (eds), International Civil Litigation in Europe and Relations with Third States (Brussels, Bruylant, 2005) 157; R Michaels, 'Two Paradigms of Jurisdiction' (2007) 27 Michigan Journal of International Law 1003, 1017-22.

${ }_{14} 15$ USC s 22 provides that: 'Any suit, action, or proceeding under the antitrust laws against a corporation may be brought not only in the judicial district whereof it is an inhabitant, but also in any district wherein it may be found or transacts business; and all process in such cases may be served in the district of which it is an inhabitant, or wherever it may be found'.

${ }^{15}$ Note that in cases brought under federal statutes, the due process analysis considers national contacts in the aggregate, rather than contacts with individual States.

${ }_{16}$ RJ Weintraub, 'Negotiating the Long-Arm Provisions of the Judgments Convention' (1998) 61 Albany Law Review 1269, 1271-73; R Brand, 'Due Process, Jurisdiction and a Hague Convention' (1999) 60 University of Pittsburgh Law Review 661, 695.

${ }^{17}$ Keeton v Hustler Magazine 465 US 770 (1984); Calder v Jones 465 US 773 (1984). 
This basis, which constitutes a sort of effects doctrine for matters of personal jurisdiction, can be translated to the antitrust context. Unlike in Article 1 Brussels I Regulation, therefore, mere effects (or injury) within the United States are not sufficient for the assertion of jurisdiction; the defendant must also have specifically targeted the US market.

The difficulty arises in determining whether anti-competitive conduct is in fact specifically aimed at a particular jurisdiction. ${ }^{18}$ The Court of Appeals for the Second Circuit found this requirement to have been met in a case in which a representative of the defendant was shown to have attended a meeting in Seoul, Korea, the minutes of which provided direct evidence of price fixing specifically in the US market. Where such clear evidence is lacking, plaintiffs face difficulties. For example, the Ninth Circuit rejected a claim that a contract aimed at the US market, pointing out that the United States was not named in the contract. ${ }^{19}$ It is noteworthy that the standard is different in different States. Thus, in one recent case involving a Belgian defendant, the DC Circuit held that a worldwide price-fixing agreement failed to reach the degree of specificity required by the long-arm statutes of eight States, but did meet the standard required by the laws of California and Illinois. ${ }^{20}$

This basis of jurisdiction works well where conduct is indeed aimed at a specific market, or where evidence makes it clear that a particular market was among the intended markets. However, global price fixing is often not aimed at a particular market but instead at the world at large, leading to the ironic result that personal jurisdiction becomes harder to establish the more global the price fixing is. ${ }^{21}$ Courts have noted the irony that emerges if ' $a$ party can avoid liability by multiplying its wrongdoing, ${ }^{22}$ but a real solution to the problem is not, it appears, in sight.

\section{ii. Conspiracy}

One core interest in antitrust litigation is the ability to concentrate all members of a cartel in a single lawsuit. In the Brussels I regime, this is achieved with Article 6(1). In US law, the most important jurisdictional basis for this purpose is provided by the conspiracy doctrine. ${ }^{23}$ According to this theory, which is accepted in some but not all States, jurisdiction can be exercised over all members of a conspiracy under four conditions:

1. the defendant and one or more persons conspired to do something;

2. that they could reasonably expect to lead to consequences in a particular forum;

3. one co-conspirator commits overt acts in furtherance of the conspiracy; and

4. those acts are of a type which, if committed by a non-resident, would subject the nonresident to personal jurisdiction under the long-arm statute of the forum State. ${ }^{24}$

${ }^{18}$ L Dougherty, 'Note: Does a Cartel Aim Expressly? Trusting Calder Personal Jurisdiction When Antitrust Goes Global’ (2008) 60 Florida Law Review 915, 932-36.

19 McGlinchy $v$ Shell Chemical Co 845 F 2d 802, 817 (9th Cir 1988).

${ }^{20}$ Re Vitamins Antitrust Litigation US Dist LEXIS 25073 (D DC 2001); discussed in Dougherty, 'Note' (n 18) 937-41.

${ }^{21}$ See Northwest Aluminum Co v Hydro Aluminum Deutschland GmbH No 02-398-JE, 2003 WL 23571744, 4-5 (D Or 2003); cf Re Bulk [Extruded] Graphite Prods Antitrust Litigation No 02-6030 (WHW), 2007 WL 2212713, 9 (D NJ 2007).

22 Cole v Tobacco Inst 47 F Supp 2d 812, 815 (ED Tex 1999).

${ }^{23}$ eg, United Phosphorus Ltd v Angus Chemical Co 43 F Supp 2d 904, 912 (ND Ill 1999).

${ }^{24}$ Cawleyv Bloch 544 F Supp 133, 135 (D Md 1982). 
This doctrine creates a mechanism roughly comparable to Article 6(1) Brussels I Regulation, but with an important difference: ${ }^{25}$ it is based on specific jurisdiction over one of the defendants based on that defendant's acts, not on the domicile of one of the parties. Article 6(1)'s emphasis on domicile makes that jurisdictional basis especially inadequate for antitrust matters (for which reason it might be remodelled along the lines of Article 6(3)(b) Rome II Regulation). On the one hand, Article 6(1) is not available if all members of a cartel are domiciled outside the European Union, although such cases may be particularly important. On the other hand, Article 6(1) enables plaintiffs to find a dummy defendant in a Member State in order to assert jurisdiction over everyone else. The Provimi litigation in the UK illustrates this danger particularly clearly, as Michael Wilderspin's contribution suggests. ${ }^{26}$ In fact, the approach taken in Article 6(1) Brussels I would likely be incompatible with the due process clause, because it would not afford adequate protection to the defendant not domiciled in the forum. By contrast, conspiracy jurisdiction is considered constitutional as long as the act on which jurisdiction is based is attributable to the conspiracy members. ${ }^{27}$ Moreover, it is more likely to concentrate litigation in the natural forum.

\section{B. Forum non Conveniens}

Even if a court has jurisdiction, it may decide not to assert that jurisdiction if it concludes that it is an inappropriate forum and that an adequate alternative forum is available elsewhere. Forum non conveniens is based, in US law, on a combination of public and private factors: public interest in regulation, and private interests in convenience. In a global economy, where anti-competitive conduct has effects on various domestic markets, the availability of forum non conveniens is therefore a particularly important element of procedure. This doctrine is especially relevant in the context of multinational class actions, because the presumption in favour of a plaintiff's choice of forum is weaker when the plaintiff is foreign. ${ }^{28}$ Thus, a court might feel that the claims of foreign plaintiffs within a class are subject to dismissal on the basis of this doctrine, whether those claims are brought alone or in connection with the claims of US plaintiffs.

The use of forum non conveniens to dismiss claims brought under US antitrust law is a relatively recent development. In 1948, the US Supreme Court decided, in National City Lines I, that the venue provision of the Clayton Act, which expanded the number of judicial venues open to plaintiffs, precluded the application of forum non conveniens to antitrust claims. ${ }^{29}$ That holding was legislatively overruled for domestic cases in 1948, when 28 USC section 1404(a) was adopted to enable the transfer of a case from one district court to another. ${ }^{30}$ This left open the question whether forum non conveniens should be available for international antitrust cases, where direct transfer to the other court is impossible. Caselaw on this question reveals three different approaches. The Fifth Circuit has held that National City Lines I is good law for international cases, making forum non conveniens

\footnotetext{
${ }^{25}$ See W Dodge, 'Antitrust and the Draft Hague Judgments Convention' (2001) 32 Law \& Policy in International Business 363, 371-72.

${ }^{26}$ See in this book the contribution of M Wilderspin.

${ }^{27}$ Re Vitamins (n 20) 41 fn 8; see also A Althouse, 'The Use of Conspiracy Theory to Establish Personal Jurisdiction: A Due Process Analysis' (1983) 52 Fordham Law Review (Fordham L Rev) 234.

28 Piper Aircraft Co v Reyno 454 US 235, 255 (1981).

29 US v National City Lines Inc 334 US 573 (1948) (National City Lines I).

30 US v National City Lines Inc 337 US 78, 80 (1949) (National City Lines II).
} 
unavailable; that position has also received some support in the literature. ${ }^{31}$ The District Court for the District of Columbia, while admitting the theoretical possibility of forum non conveniens dismissal, has suggested that the public interest in antitrust enforcement, reflected in the availability of treble damages, trumps private interests in litigating elsewhere - especially in view of the differences in antitrust laws across legal systems. ${ }^{32}$ On this view, forum non conveniens dismissal is effectively unavailable. Finally, a Second Circuit decision from 1998 represents the first case in which an appellate court dismissed a plaintiff's antitrust claims in favour of a foreign forum. ${ }^{33}$ That court noted that the relevant provisions of EU antitrust law were 'roughly analogous' to the provisions of the US Sherman Act, ${ }^{34}$ and that the plaintiff would therefore be able to assert a private right of action in England. On that basis, it concluded that the English forum was adequate. ${ }^{35}$

That decision has so far stood relatively alone, at least in the antitrust context, but it might nonetheless signal a broader trend. Many of the earlier cases had precluded forum non conveniens dismissal on the basis that US antitrust policies and remedies were unique, and that any such dismissal would therefore function as a decision in favour of the defendants. This has changed now that antitrust enforcement, including through private remedies, is more broadly available worldwide. The recent Empagran decision of the US Supreme Court, though not directed explicitly at questions of forum non conveniens, can be read to condone a presumption that consumers are normally expected to sue in their home courts. ${ }^{36}$ In addition, claims brought under foreign, rather than US, antitrust law are routinely dismissed on grounds of forum non conveniens. ${ }^{37}$

\section{Applicable Law}

\section{A. Actions for Monetary Damages}

\section{i. Damages Claims as Part of Applicable Antitrust Law}

In the European context, much discussion is devoted to the distinction between the applicable antitrust law and the law applicable to a claim for damages. ${ }^{38}$ This distinction plays no

\footnotetext{
31 Industrial Investment Development Corp v Mitsui \& Co 671 F 2d 876, 890-91 (5th Cir 1982), reversed on other grounds, 460 US 1007 (1983); JC Bates, 'Home is Where the Hurt is: Forum non conveniens and Antitrust' (2000) University of Chicago Legal Forum 281, 295-326.

${ }^{32}$ El Cid Ltd v New Jersey Zinc Co 444 F Supp 845, 846 (SD NY 1977); Laker Airways Ltd v Pan American World Airways, 568 F Supp 811, 817-18 (D DC 1983); National Hockey League Players' Association v Plymouth Whalers Hockey Club 166 F Supp 2d 1155 (ED Mich 2001).

33 Capital Currency Exchange NV v National Westminster Bank PLC 155 F 3d 603 (2d Cir 1998).

${ }^{34}$ ibid 610.

35 cf National Hockey League Players' Association (n 32) (recognising the availability of forum non conveniens in antitrust cases but holding that Ontario, Canada was an inadequate alternative forum).

${ }^{36}$ F Hoffmann-LaRoche v Empagran SA 542 US 155 (2004). Forum non conveniens was raised during oral argument; $c f$ discussion in SL Diamond, 'Empagran, the FTAIA and Extraterritorial Effects: Guidance to Courts Facing Questions of Antitrust Jurisdiction Still Lacking' (2006) 31 Brooklyn Journal of International Law 805, 848-55; see also JT Schmidt, 'Keeping US Courts Open to Foreign Antitrust Plaintiffs: A Hybrid Approach to the Effective Deterrence of International Cartels' (2006) 31 Yale Journal of International Law (YJIL) 211, 253-56.

37 See, eg, Re Air Cargo Shipping Services Antitrust Litigation 2008 WL 5958061, 24-30 (ED NY 2008); Re Urethane Antitrust Litigation 2010 WL 398094, 7 (D Kan 2010); see also further discussion in III.A.iv below.

${ }_{38}$ See Basedow, 'Jurisdiction and Choice of Law' (n 5) 237 ff; see also in this book the contribution of S Francq and W Wurmnest, part IV.B.
} 
role under US law. Here, the right of action for compensation for harm flowing from a violation of the antitrust laws is itself granted by the antitrust laws. This means that the same conflict-of-laws considerations relevant to the applicability of US antitrust law also determine whether the damages claim exists. This is true of claims that arise both within and outside contractual relationships; therefore, the difficult characterisation issues that present themselves in Europe (where contractual and non-contractual claims are governed by two entirely different instruments, namely the Rome I and Rome II Regulations) do not occur. At the root of this parallel treatment is the public, regulatory function of the claim. The claim for damages is granted predominantly for regulatory purposes - to enable the private plaintiff to enforce antitrust law as a private attorney general. ${ }^{39}$ While the US Supreme Court has suggested that the territorial scope of the antitrust laws might be narrower in private claims than when the government brings suit, ${ }^{40}$ the legal basis for such a distinction is not clear.

Even where, as in the European context, the delictual claim is perceived as separate from substantive antitrust law, ${ }^{41}$ it is not clear why it should be governed by a different set of rules unless absolutely necessary. Of course, separate determination of the applicable law is necessary where the law applicable to the substance of the antitrust violation does not itself confer a delictual or quasi-delictual right of action, as is the case with EU law. ${ }^{42}$ Apart from that situation, however, the US experience suggests that Article 6(3)(a) should be interpreted in alliance with the rules determining the applicability of substantive antitrust law.

\section{ii. Effects Doctrine}

According to Article 6(3)(a) Brussels I Regulation, the law applicable to a damages claim is determined by the affected market. While this provision is reminiscent of the Wood Pulp jurisprudence of the Court of Justice, its language, surprisingly, more closely resembles the effects doctrine that was established in the United States in 1945 and has been adopted in many jurisdictions since. ${ }^{43}$

Under the original formulation of the US effects doctrine, US antitrust law would apply to anti-competitive conduct that had effects on US markets as long as those effects were intended. ${ }^{44}$ This extremely unilateral approach was later softened in the face of protests from other countries. First, with respect to the strictly unilateral aspect of the doctrine, not any effects will do (as the Alcoa case of 1945 had already suggested). Rather, what is required, in the words of the Foreign Trade Antitrust Improvement Act (FTAIA) of 1982, which attempted to codify the effects doctrine, are effects that are 'direct, substantial, and reasonably foreseeable. ${ }^{45}$

${ }^{39}$ See $\mathrm{n} 4$.

${ }^{40}$ Empagran (n 36) 170-71; PB Stephan III, 'Empagran: Empire Building or Judicial Modesty?' available at http://ssrn.com/abstract=1559879.

${ }^{41}$ See the contribution of S Francq and W Wurmnest.

${ }^{42}$ Basedow (n 5) 237-39. The White Paper on damages actions does not envisage a full set of European rules on compensation.

${ }^{43}$ See I Schwartz and J Basedow, 'Restriction of Competition' in K Lipstein (ed), International Encyclopedia of Comparative Law, vol III (Tübingen/The Hague, Mohr Siebeck/ Martinus Nijhoff Publishers, 1995) ch 35.

${ }^{44}$ US v Aluminum Co of America 148 F 2d 416 (2d Cir 1945).

4515 USC s 6a provides as follows:

'Sections 1 to 7 of this title shall not apply to conduct involving trade or commerce (other than import trade or import commerce) with foreign nations unless -

(1) such conduct has a direct, substantial, and reasonably foreseeable effect - 
Second, the regulatory interests of other nations matter too, though it is not clear to what extent. In the 1970s, the Ninth Circuit, in Timberlane, restricted the applicability of US law on the basis of international comity. Under this approach, US law would be applicable only if the regulatory interest of the United States and the effects on the US market were sufficiently strong (though not necessarily stronger) vis-a-vis those of other countries; the case also listed a number of criteria to be used in determining that balance. ${ }^{46}$ Not all courts agreed that the applicability of US law should be limited in this way, however. The role of comity in the analysis became even less clear when a majority of the US Supreme Court, in the 1993 Hartford Fire decision, held that comity should not even be considered unless different potentially applicable laws gave rise to incompatible requirements. ${ }^{47}$ To use the example of that case, this meant that US antitrust law could apply to forbid certain collusive conduct by English reinsurers aimed at the US market, even though the collusion was legal under English law and regardless of any regulatory interest the UK might have had in allowing the conduct in question. Justice Scalia's dissent in Hartford Fire had emphasised the importance of comity considerations vis-a-vis foreign regulatory interests ${ }^{48}$ and in the US Supreme Court's 2004 Empagran decision, the majority seemed to embrace his argument. That case re-established the importance of international comity, ${ }^{49}$ while at the same time rejecting as too complex the type of case-by-case analysis favoured in Timberlane. As a result, the exact conditions under which US antitrust law may be applied on the basis of effects remain unclear.

\section{iii. Concentration of Applicable Law}

Particular difficulties arise when effects occur both inside and outside the forum State, especially in the case of a global cartel. The traditional European solution to such cases is the 'mosaic principle', according to which different laws would apply to claims arising from injury in different places. This solution is unavailable to US courts, however, to the extent that foreign regulatory law is inapplicable. As a result, only injuries suffered in the United States could be the subject of claims before US courts - similar to the solution adopted by the ECJ in Shevill..$^{50}$ In fact, the solution would be even less satisfactory; while Shevill at least would allow full recovery at the defendant's domicile, that outcome is not possible under US law.

(A) on trade or commerce which is not trade or commerce with foreign nations, or on import trade or import commerce with foreign nations; or

(B) on export trade or export commerce with foreign nations, of a person engaged in such trade or commerce in the United States; and

(2) such effect gives rise to a claim under the provisions of sections 1 to 7 of this title, other than this section.

If sections 1 to 7 of this title apply to such conduct only because of the operation of paragraph (1) (B), then sections 1 to 7 of this title shall apply to such conduct only for injury to export business in the United States'.

${ }^{46}$ Namely 'the degree of conflict with foreign law or policy, the nationality or allegiance of the parties and the locations or principal places of business of corporations, the extent to which enforcement by either State can be expected to achieve compliance, the relative significance of effects on the United States as compared with those elsewhere, the extent to which there is explicit purpose to harm or affect American commerce, the foreseeability of such effect, and the relative importance to the violations charged of conduct within the United States as compared with conduct abroad', Timberlane Lumber Co v Bank of America NT and SA 549 F 2d 597, 614 (9th Cir 1976).

47 Hartford Fire Ins v California 509 US 764, 797-99 (1993).

48 ibid 817-21.

49 Albeit on facts that did not, in the Court's reading, implicate any effects on US markets, thus distinguishing the case from Hartford Fire Ins $v$ California (n 47).

${ }^{50}$ Case C-68/93 Fiona Shevill and others v Presse Alliance SA [1995] ECR I-415; cf Basedow (n 5) 250. 
These questions were at stake in a series of cases addressing global cartels, one of which, Empagran, was decided by the US Supreme Court. ${ }^{51}$ Empagran dealt with a global vitamins cartel that had fixed prices both within the United States and abroad. Plaintiffs had purchased vitamin products in foreign markets, but argued that the cartel's effects within the United States justified the application of US antitrust law to their claims. Three strands of this argument may be identified.

The first argument, derived from an earlier US Supreme Court decision, ${ }^{52}$ is that the United States has a direct regulatory interest in applying its law to these claims. If US law does not apply, the argument goes, such cartels would be insufficiently deterred: they would face treble damages only with regard to injuries suffered in the United States, and could offset those losses with gains in other markets. As a result, US consumers and US courts would continue to suffer the results of ongoing cartel activity. The US Supreme Court in Empagran rejected this argument without much discussion, at least on the assumption that the injuries suffered by the plaintiffs were independent of the effects in the United States.

The second argument was that the cartel's effects within the United States had caused the plaintiff's injuries, despite the fact that they had transacted on foreign markets. The US Supreme Court did not address this argument, simply assuming that the injuries outside the United States were completely independent from those within the United States, but remanded this issue to the lower court. In the resulting case, the DC Circuit Court of Appeals addressed directly the plaintiffs' 'arbitrage' argument:

Because the appellees' product (vitamins) was fungible and globally marketed, they were able to sustain super-competitive prices abroad only by maintaining super-competitive prices in the United States as well. Otherwise, overseas purchasers would have purchased bulk vitamins at lower prices either directly from US sellers or from arbitrageurs selling vitamins imported from the United States, thereby preventing the appellees from selling abroad at the inflated prices. Thus, the super-competitive pricing in the United States 'gives rise to' the foreign super-competitive prices from which the appellants claim injury..$^{53}$

The court rejected this argument. It held that the foreign purchasers needed to establish not merely but-for causation, but 'a direct causal relationship' between anti-competitive effects in the United States and the harm suffered in foreign transactions. ${ }^{54}$ Where the connection between US prices and that harm was only indirect - as the court in that case concluded - US jurisdiction could not be established.

Subsequent cases heard in a number of additional courts - including the Eighth and Ninth Circuit Courts of Appeals - have followed the DC Circuit's reasoning in Empagran II. ${ }^{55}$ Adopting the restrictive view of causation, these courts have concluded that it is the foreign effects of global anti-competitive behaviour (increased prices abroad), not the domestic effects of such behaviour (increased US prices), that are the proximate cause of foreign purchasers' harm. ${ }^{56}$ Therefore, such claims do not fall within the scope of US antitrust law. This line of cases has led one commentator to conclude that the 'ability of foreign

51 Empagran (n 36).

${ }^{52}$ Pfizer Inc $v$ Government of India 434 US 308 (1978).

${ }^{53}{ }^{53}$ Empagran SA v F Hoffmann-LaRoche Ltd 417 F 3d 1267, 1270 (DC Cir 2005) (footnote omitted).

54 ibid.

55 See, eg, Re Dynamic Random Access Memory (DRAM) Antitrust Litigation 546 F 3d 981 (9th Cir 2008); Re Monosodium Glutamate Antitrust Litigation 477 F 3d 535 (8th Cir 2007); Emerson Electric Co v Le Carbone Lorraine SA 500 F Supp 2d 437 (D NJ 2007).

${ }_{56}$ Re Monosodium Glutamate (n 55) 541. 
plaintiffs to bring claims in the US courts [for] most versions of the globally indivisible market theory' is becoming severely limited. ${ }^{57}$

A final argument, one less prominent in the discussion, concerns procedural efficiency: litigation concerning the entire cartel should be concentrated in one court, ideally with the application of just one law. In public enforcement of antitrust law, such arguments have led to the implementation of 'positive comity': in a cartel affecting both the United States and the European Union, agencies in both countries will agree which of them should engage in enforcement procedures, taking into account both institutions' regulatory interests. ${ }^{58} \mathrm{~A}$ similar position has been suggested, in the influential District Court for the Southern District of New York, for the law applicable to multistate torts (though the relevant decision was not upheld). In the antitrust context, such an argument has not been successful after the Empagran decision.

Concentration of the law applicable in such cases is, arguably, a goal of Article 6(3)(b) Rome II Regulation, which provides for the application of the lex fori to all claims arising from a cross-border cartel. That provision, it can be assumed, was influenced by the Empagran decision as well as by European litigation arising from the vitamin cartel. It is noteworthy that the interest in effective private enforcement, which was voiced especially by the EU Commission in support of the provision, ${ }^{59}$ is now realised more fully in Europe than in the United States. The only surprising restriction, from a US perspective, is that Article 6(3)(b) Rome II Regulation allows only for the choice of the law of the defendant's domicile, ${ }^{60}$ which means that defendants from EU Member States are, ironically, disadvantaged vis-a-vis defendants from third States.

\section{iv. Application of Foreign Law}

As noted above, US courts have no original federal question jurisdiction over claims based on the violation of foreign antitrust law. However, in a small handful of cases, while not engaging in traditional multilateral choice-of-law analysis, US courts have considered whether to apply foreign antitrust law to particular claims. These claims were presented on the basis of supplemental jurisdiction, pursuant to which a court may exercise jurisdiction over claims that are 'so related to claims [subject to the court's] original jurisdiction that they form part of the same case or controversy'. In other words, where the conduct in question had also given rise to claims under US antitrust law, foreign claimants may seek to have the US court adjudicate their claims as well. ${ }^{61}$

One limitation to this tactic is that the court must have a 'hook' for such claims, in the form of claims that are subject to its original jurisdiction. The Empagran litigation demonstrates the difficulty that may result from this requirement. In that case, the plaintiff class on remand included only foreign purchasers, as the US claimants had by that point settled their claims. When the foreign plaintiffs asserted claims under EU law, on the ground of supplemental jurisdiction, the court declined, noting the absence of jurisdiction over a 'main' cause of action under US law. ${ }^{62}$ Thus, the Sherman Act did not apply because the

57 SW Waller, Antitrust \& American Business Abroad, vol I, 3rd edn (St Paul, West Group, 1997) para 9:7B.

${ }^{58}$ See B Zanettin, Cooperation between Antitrust Agencies at the International Level (Oxford, Hart Publishing, 2002) 183 ff; ABA Section of Antitrust Law, International Antitrust Cooperation Handbook (2004) 44-45.

59 See in this book the contribution of S Francq and W Wurmnest.

${ }^{60}$ See the contribution of S Francq and W Wurmnest, part VI.

${ }^{61} 28$ USC s 1367(a).

${ }^{62}$ Empagran SA v F Hoffman-La Roche Ltd 453 F Supp 2d 1, 12-13 (D DC 2006). 
injuries in question were not within its scope of application, and foreign antitrust law could not be applied by the court because there was no basis for jurisdiction over the plaintiffs' claims.

Other limitations are posed by the various procedural tools that courts can use to dismiss claims brought in this way. One mechanism is provided by the standard for supplemental jurisdiction itself, which is discretionary. Section 1367(a)(c) provides that courts may decline the exercise of supplemental jurisdiction where:

1. the claim raises a novel or complex issue of State law;

2. the claim substantially predominates over the claim or claims over which the district court has original jurisdiction;

3. the district court has dismissed all claims over which it has original jurisdiction; or

4. in exceptional circumstances, there are other compelling reasons for declining jurisdiction.

This provision gives courts substantial latitude to dismiss claims based on foreign regulatory law. ${ }^{63}$ One recent decision, Re Urethane, ${ }^{64}$ explores the range of factors that courts consider in the exercise of this discretion. Addressing the possibility of supplemental jurisdiction over claims brought under European antitrust law, the court emphasised the novel, complex and 'unsettled' nature of that law; the likelihood that the European law claims, which would require the consideration of multiple Member States' laws, would predominate over the US law claims; the interest in comity and international cooperation; and the fact that the claims would be more conveniently litigated in a European forum. On the basis of all those factors, it declined to exercise supplemental jurisdiction over the foreignlaw claims.

Moreover, the courts have at their disposal all of the other procedural doctrines customarily used to decline jurisdiction over claims more closely connected to other jurisdictions. Another recent decision, Re Air Cargo Shipping Services, ${ }^{65}$ contains an extensive analysis that illustrates the reluctance of US courts to apply foreign antitrust law. In that case, the court dismissed claims brought under EU antitrust law on the basis of forum non conveniens. Two arguments for dismissal are particularly relevant to our analysis. First, the court invokes a long-standing (though disputed) jurisprudence according to which the choice of a forum deserves less deference if made by a foreigner than if made by a US domiciliary (or, put differently, the choice deserves more deference when made for the plaintiff's own home courts) ${ }^{66}$ Second, it invokes the difficulty of the choice-of-law analysis and the multitude of potentially applicable foreign laws as a reason for forum non conveniens dismissal:

[T] he court will likely need to decide which national member state's laws should apply to each set of claims arising out of the shipping routes. It appears certain that the court will need to choose and apply the laws of over thirty foreign jurisdictions. The complexity inherent in the determination and application of foreign law weighs in favor of dismissal. ${ }^{67}$

The court felt that European courts were better equipped to deal with these claims also as a matter of comity, because they could defer matters to the European Court of Justice

${ }^{63}$ Similarly Information Resources Inc v Dun \& Bradstreet Corp 127 F Supp 2d 411 (SD NY 2000).

${ }^{64}$ Re Urethane (n 37).

${ }^{65}$ Re Air Cargo Shipping Services (n 37) $24 \mathrm{ff}$.

${ }_{66}$ ibid 25 (citing Piper Aircraft Co v Reyno (n 28) 235).

67 ibid 30. 
and because Europe had an interest in developing its own antitrust law - especially in the area of private antitrust enforcement. There is no invocation of a public law taboo per se, but the court does identify a difference between foreign contract, tort, and property law, which it considers easy to apply, and foreign antitrust law, which it does not. ${ }^{68}$ Thus, while considering many of the same factors that the Re Urethane court analysed, it did so within the framework of forum non conveniens rather than supplemental jurisdiction. This seems to be the procedurally sounder approach in class actions where minimal diversity is present. ${ }^{69}$ In such cases, the court would have original jurisdiction over the foreign claims on the basis of diversity, and therefore would not require an independent basis in the form of supplemental jurisdiction.

At least one opinion does apply foreign antitrust law, ${ }^{70}$ although it does not create a strong precedent. The case involved allegations under both EU antitrust law and the Greek civil code. The court discusses, summarily, the content of the relevant provisions, and then dismisses the plaintiff's complaint for 'failure to state a claim' - meaning, essentially, that the plaintiff's own factual allegations do not substantiate the legal claim. ${ }^{71}$ It is difficult to ascertain on the basis of this summary application of Greek antitrust law whether the court had concluded that the Greek law did indeed apply to the claims. The court may simply have decided that the viability of the claim was either prior to questions of applicable law, or easier to answer. Moreover, the opinion contains no specific choice-of-law discussion (a similarity, incidentally, with the other supplemental jurisdiction cases). Nonetheless, as far as it goes this is a decision that addresses foreign antitrust law as a possible basis for a claim, and it seems remarkable that the court never mentions a public law taboo (again, a similarity with the supplemental jurisdiction cases).

\section{B. Contract Validity}

Many antitrust disputes originate in a contractual relationship, such as a distribution arrangement or licensing agreement. In that setting, anti-competitive conduct that violates the antitrust laws may simultaneously be a breach of contract; alternatively, and more frequently, allegations of antitrust violations may be asserted as a defence to a claim for breach of contract.

Claims for damages based on violations of US antitrust laws are largely covered by section 4 Clayton Act, even when they arise out of a contractual relationship. ${ }^{72}$ Thus, the most important choice-of-law issue remaining in the area of contract relates to validity. A conflict-of-laws situation will result if the contract is governed by a different law from that governing the antitrust violation invoked as a defence to the contract's enforceability. This is often the case, as applicable contract law is determined by rules different from those used to determine applicable antitrust law. ${ }^{73}$

68 ibid 33-34.

69 See the text accompanying n 12.

70 Multi-Juice SA v Snapple Beverage Corp 2003 WL 1961636 (SD NY 2003).

71 ibid 5.

72 II.A.i above.

${ }^{73}$ If the law governing the contract is determined by the place of performance, this place will sometimes coincide with the place of effects: see, eg, Wyatt Energy Inc v Motiva Enterprises LLC 936 A 2d 280, 287 (Conn App 2007). 


\section{i. Party Autonomy}

Parties cannot choose applicable antitrust law, nor can the choice of a law to govern the contract render inapplicable an antitrust law that would otherwise apply. By use of arbitration agreements, however, parties may diminish the likelihood that different laws will govern the contract, on the one hand, and an antitrust-based challenge to its validity, on the other. Historically, US courts held validity challenges based on antitrust law apart from contract-based claims, on the basis that they were not amenable to party choice of forum or law. As the public policy in favour of arbitration gained strength, however, this attitude began to change. In the watershed Mitsubishi case, ${ }^{74}$ the Supreme Court held that statutory antitrust claims were arbitrable; subsequent cases have interpreted submissions to arbitrate very broadly, to cover not just contract claims but all claims arising out of the contractual relationship, ${ }^{75}$ and to allow for arbitration even of domestic, not just international, antitrust claims. ${ }^{76}$ While arbitrators may apply provisions of mandatory law (such as antitrust law), they are not obliged to do so against the parties' will. ${ }^{77}$ As a result, insofar as US courts are willing to enforce arbitration agreements even if the arbitrator is likely to apply another (or no) antitrust law, ${ }^{78}$ some conflicts between US law and foreign law may be avoided.

Apart from this special situation, an antitrust-based challenge to the validity of a contract will often arise under a different law than that governing the contract itself.

\section{ii. Federal Antitrust Law and State Contract Law}

The most frequent situation for such a conflict of laws in the US system concerns the relationship between federal law and State law. In Europe, Article 101(2) TFEU (formerly Article 81(2) EC) explicitly invalidates contracts that violate EU antitrust law, regardless of the applicable contract law, due to the supremacy of EU law. In the United States, section 1 Sherman Act merely declares such contracts to be 'illegal' without spelling out precisely the consequences for the contract. ${ }^{79}$ Not long after the Sherman Act was enacted, the US Supreme Court decided that its violation could create a defence against actions for the enforcement of contract, ${ }^{80}$ though this doctrine, as an equitable one, is subject to limitations. This typically creates a dépeçage situation: given that there is no general federal contract law, contracts are normally governed by State law, whereas the defence is based on federal law. On the one hand, State law cannot trump federal law, suggesting that the

\footnotetext{
${ }^{74}$ Mitsubishi v Soler Chrysler-Plymouth 473 US 614 (1985).

75 See, eg, High Strength Steel Inc v Svenskt Stal Aktiebolag 1985 WL 2546 (ND Ill 1985).

${ }^{76}$ Kotam Electronics Inc v JBL Consumer Products Inc 93 F 3d 724 (11th Cir 1996); Re Cotton Yarn Antitrust Litigation 505 F 3d 274, 282 (4th Cir 2007).

77 See AS Rau, 'The Arbitrator and 'Mandatory Rules of Law' (2007) 18 American Review of International Arbitration 51.

${ }^{78}$ See also Simula Inc v Autoliv Inc 175 F 3d 716 (9th Cir 1999). That case involved parties to a development and licensing agreement. The plaintiff alleged that the agreement unlawfully restrained trade under US law; the defendant moved to compel foreign arbitration under the agreement's dispute resolution clause. Unlike in Mitsubishi, the court in this case, which granted the motion to compel arbitration, explicitly addressed and accepted - the possibility that foreign antitrust law, not US law, would be applied in the arbitration. $c f$ HL Buxbaum, 'The Private Attorney General in a Global Age: Public Interests in Private International Litigation' (2001) 26 YJIL 219, 243-44; SK Mehra, 'Deterrence: The Private Remedy and International Antitrust' (2002) 40 Columbia Journal of Transnational Law 275, 314-15.

${ }_{79} 15$ USC s 1 provides in part that 'Every contract, combination in the form of trust or otherwise, or conspiracy, in restraint of trade or commerce among the several States, or with foreign nations, is declared to be illegal'.

${ }^{80}$ E Bement \& Sons v National Harrow Co 186 US 70, 88 (1902).
} 
consequences of a violation of the Sherman Act must be a matter of federal law. ${ }^{81}$ On the other hand, the US Supreme Court has also stated that, since the rights and duties of contract parties in general are governed by State law, the federal courts 'should not be quick to create a policy of non-enforcement of contracts beyond that which is clearly the requirement of the Sherman Act. ${ }^{82}$ This issue will not necessarily be tested in federal courts: because the action brought is based in contract, the exclusive federal-question jurisdiction of the federal courts is not triggered. As a consequence, such claims can be brought before State courts. Further, even if they are brought before (or transferred to) federal courts on the basis of diversity of citizenship, the federal courts will be obliged to apply State law.

\section{iii. US Antitrust Law and Foreign Contract Law}

Presumably, the result of such a conflict is the same when the law governing the contract is not that of a US State but instead that of a foreign country. A contract otherwise governed by foreign law could be subject to a defence based on a violation of US antitrust law. Even following the principle from the federal-State context that the consequence of such a violation is a matter of contract, and must therefore be subject to the law governing the contract, it seems quite clear that such law would not be applied to enforce the contract if it did not allow for the proper consideration of US antitrust law.

\section{iv. Foreign Antitrust Law and State Contract Law}

The same type of conflict should appear where the conflict is between domestic contract law and the antitrust law of a foreign nation. The situation in which a contract is challenged on the basis of a violation of foreign antitrust law has not, it appears, yielded case-law. On the one hand, illegality under foreign law can be a defence to contract under US conflict of laws. ${ }^{83}$ On the other hand, such a defence could trigger the public law exception (the public law taboo).$^{84}$ The defence would fall squarely under the original justification of the penal and the revenue rule, namely that private rights (here, of contract enforcement) should not be undermined by foreign public law.

The public law taboo does not hold fully, however. US courts have refused to enforce contracts otherwise governed by domestic law that violated European ${ }^{85}$ or Chinese licensing requirements. ${ }^{86}$ An especially interesting decision in this context is Kashfi $v$ PhibroSalomon $I n c{ }^{87}$ In that case, a contract governed by New York law was denied enforcement because it intended the violation of an Iranian penal statute criminalising influence on governmental officials. ${ }^{88}$ No mention is made of the penal rule; instead, the court points

\footnotetext{
${ }^{81}$ Sola Electric Co $v$ Jefferson Electric Co 317 US 173, 176 (1942): 'When a federal statute condemns an act as unlawful the extent and nature of the legal consequences of the condemnation, though left by the statute to judicial determination, are nevertheless federal questions, the answers to which are to be derived from the statute and the federal policy which it has adopted. To the federal statute and policy, conflicting state law and policy must yield'.

${ }^{82}$ Kelly v Kosuga 1358 US 516, 518 (1959).

${ }^{83}$ Rest 2d Conflict of Laws s $202 \mathrm{cmt}$ (c).

84 WS Dodge, 'Breaking the Public Law Taboo' (2002) 43 Harvard ILJ 161, 185-87.

${ }^{85}$ Dornberger v Metropolitan Life Ins Co 961 F Supp 506, 533 (SD NY 1997).

${ }^{86}$ Lehman Bros Commercial Corp v Minmetals International Non-Ferrous Metals Trading Co 179 F Supp 2d 118, 138-39 (SD NY 2001).

${ }^{87}$ Kashfiv Phibro-Salomon Inc 628 F Supp 2d 727 (SD NY 1986).

88 ibid 737.
} 
out that the contract also contravenes the public policy of the United States. ${ }^{89}$ Applied to the antitrust context, this would suggest that a contract aimed at the violation of foreign antitrust law would be illegal, at least where, pari passu, it would also violate US antitrust law. Nevertheless, there is no clear precedent on this issue.

\section{Conflict-of-Laws Issues in Class Action Certification}

International antitrust cases in US courts frequently involve class actions, as that form of representative litigation is used by multiple plaintiffs to concentrate their claims in US fora. In such cases, the particular procedural mechanisms of class action practice in the United States intersect with various conflict-of-laws issues. As the sections below describe, conflicts questions play a role in determining whether a class can be certified at all.

\section{A. Jurisdiction Over Non-Resident Class Members}

In two-party relations, personal jurisdiction is usually an issue only with respect to the defendant. Minimum contacts between the plaintiff and the forum are irrelevant ${ }^{90}$ (though they can play a role for forum non conveniens analysis): 'fairness' to the plaintiff results not from such contacts, but because the plaintiff chose voluntarily to initiate litigation in the forum. In class actions, by contrast, not all plaintiffs are similarly situated. The outcome of a class action (whether dismissal, settlement or judgment) is binding not only on the plaintiff who serves as class representative, but on all members of the plaintiff class - the socalled 'absent' plaintiffs. It will therefore preclude the ability of those absent plaintiffs to assert their claims subsequently in some other forum..$^{91}$ For its disposition to have such effect, the forum court must have personal jurisdiction over all such plaintiffs. This raises the question of how jurisdiction may be established over non-resident class members, who, unlike the class representative, have not impliedly consented to jurisdiction in the forum by filing suit there.

A 1985 decision by the Supreme Court analysed the requirements for establishing personal jurisdiction over such non-resident class members. ${ }^{92}$ It began by distinguishing the litigation burdens placed on non-resident plaintiffs from those placed on non-resident defendants. It noted that absent plaintiffs are 'not haled anywhere', do not face potential liability for fees ${ }^{93}$ or for discovery costs, and will not, if unsuccessful, be forced to pay damages or comply with some other remedy. ${ }^{94}$ On this basis, it concluded that a forum State could assert personal jurisdiction over an absent plaintiff even if that plaintiff lacked the

\footnotetext{
89 ibid 739.

${ }^{90}$ Keeton $v$ Hustler Magazine (n 17) 779.

${ }^{91}$ See R Wasserman, 'Transnational Class Actions and Interjurisdictional Preclusion' (2010) University of Pittsburgh Legal Studies Research Paper Series, Working Paper No 2010-04, available at http://ssrn.com/ abstract $=1554472$ (discussing the claim-preclusive effect of both class action judgments and class action settlements under US law).

${ }_{92}$ Phillips Petroleum Co $v$ Shutts 472 US 797 (1985).

${ }_{93}$ This is the consequence of another peculiarity of US practice: the combination of the contingency fee with the 'common fund' doctrine, under which attorneys' fees may be paid out of an eventual class action recovery.

${ }_{94}$ Phillips Petroleum (n 92) 808-09.
} 
minimum contacts with the State that would be required of a non-resident defendant. ${ }^{95}$ Instead, the forum needed to provide only 'minimal procedural due process protection' - a requirement that was satisfied if absent plaintiffs received (i) adequate notice of the dispute and (ii) in actions for monetary damages, the opportunity to opt out of the class. ${ }^{96}$

Compared with jurisdictional law in other legal systems, particularly those more committed to the individual rights-based model of civil litigation, ${ }^{97}$ this appears quite permissive. The required notice of the dispute may be simply constructive: although individual notice must be given to any class members who can with reasonable effort be identified, all others receive general notification designed to reach all potential class members - for instance, through publication in appropriate news media. ${ }^{98}$ Combined with the opt-out approach - under which potential class members must affirmatively exclude themselves from the litigation if they do not wish to be bound by its outcome - this means that the claim of an individual class member might be extinguished without that member's knowledge of, let alone participation in, the litigation. In the US system, this approach is viewed as an appropriate way to maximise the class action's utility in bringing to litigation claims that would not be brought individually, as well as its deterrent function. As implemented in class actions involving claimants from systems that have made other choices regarding group litigation, however, it raises concerns regarding the sufficiency of the due process protections. $^{99}$

\section{B. Applicable Law}

When a plaintiff files an action seeking damages on behalf of a proposed class that includes foreign members, it will generally face an initial motion to dismiss the foreign claims. As noted above, US courts often conflate the questions of their own jurisdiction, on the one hand, and the scope of US antitrust law, on the other. Thus, these motions to dismiss are generally brought under Rule 12(b)(1) for lack of subject-matter jurisdiction, ${ }^{100}$ though often in connection with Rule 12(b)(6) motions for failure to assert a legally sufficient claim. ${ }^{101}$ However labelled, the courts will at this stage confront the question of applicable law. However, the choice-of-law issue may also arise in connection with the procedure for class certification, as several of the elements necessary to obtain that certification ${ }^{102}$ raise

\footnotetext{
95 ibid 811.
}

${ }_{96}$ ibid 812. The Phillips Petroleum case arose in the context of a State class action; however, the due process analysis it includes has been interpreted as applicable in the context of class actions within the federal courts as well. See CA Wright, A Miller and MK Kane (eds), Federal Practice and Procedure: Civil 3d (St Paul, West Group, 2005) para 1789.1.

${ }_{97}$ See in this book the contribution of DP Tzakas, discussing the principle of party disposition.

98 Eisen $v$ Carlisle \& Jacquelin 417 US 156 (1974).

99 See DL Bassett, 'US Class Actions Go Global' (2003) 72 Fordham L Rev 41 (arguing that in class actions seeking monetary damages, foreign absent plaintiffs should be required to opt in to the litigation).

${ }_{100}$ See, eg, Re Graphite Electrodes Antitrust Litigation 2007 WL 137684 (ED Pa 2007).

101 See, eg, Re Rubber Chemicals Antitrust Litigation 504 F Supp 2d 777 (ND Cal 2007).

102 Federal Rule of Civil Procedure 23 sets out the basis requirements of a class action. A plaintiff may sue as the representative party of a larger class if: '(1) the class is so numerous that joinder of all members is impracticable, (2) there are questions of law or fact common to the class, (3) the claims or defenses of the representative parties are typical of the claims or defenses of the class, and (4) the representative parties will fairly and adequately protect the interests of the class'. Most antitrust litigation proceeds under subpart (b)(3) of the Rule, which requires further that the common questions of law or fact must predominate over any other questions affecting individual members of the class, and that a class action is found to be superior to any other method of adjudicating the controversy in question. 
concerns related to applicable law. Class action procedure - which is of course not special to the antitrust context - is therefore another site for conflict-of-laws analysis.

One salient element in this regard is commonality. To obtain class certification under Rule 23(b)(3), a plaintiff must establish that there are questions of law or fact common to the class, and that those questions predominate over any other questions affecting individual class members. In international antitrust litigation, the claims of both US and foreign class members may all derive from the same conduct, thus presenting common issues of fact. However, absent a provision like Article 6(3)(b) Rome II Regulation, those claims will frequently be governed by different laws; therefore, a court might find that the common issues do not predominate. The operation of this requirement has been tested quite extensively in the domestic context, where plaintiffs often seek to aggregate claims arising under disparate State laws. ${ }^{103}$ The conclusion that common questions do not predominate is particularly likely where the substantive laws in questions differ substantially, as remains the case in the antitrust context. ${ }^{104}$

A second relevant element, this one relating to the role of the representative, is typicality. If the class plaintiff is a US purchaser, and proposed class members include foreign purchasers, the court might conclude that the claims of the representative are atypical of those of the rest of the class because they rest on different legal arguments. ${ }^{105}$ On this basis, litigation initiated by a US plaintiff as representative might be limited to a class of US purchasers. ${ }^{106}$

Courts also consider, under the rubric of superiority, issues of simple judicial manageability. Foreign claimants present manageability problems because it is hard to provide them with adequate notification and to keep them apprised of the litigation. ${ }^{107}$

The intersection between the question of applicable law and the question of class certification raises some interesting questions concerning the sequencing of considerations. In 'mixed class' cases, including both US and foreign claims, defendants frequently move initially to dismiss the foreign claims for failure to state a claim under US antitrust law. If such a motion is granted, the foreign plaintiffs might continue to seek adjudication of their claims under foreign antitrust law, but would face significant hurdles: first, if they relied on supplemental jurisdiction, ${ }^{108}$ the court might decline to exercise such jurisdiction based on the complexity of the foreign law questions presented. ${ }^{109}$ Second, regardless of the source of the court's jurisdiction, doctrines of forum non conveniens or comity might counsel the court to dismiss the claims - or the court might decline, on the basis of the public law taboo, to apply foreign antitrust law. Alternatively, however, a court could consider the

\footnotetext{
${ }^{103}$ In consumer protection cases, for instance, classes are sometimes proposed that include plaintiffs from multiple States whose claims are governed by different substantive laws. Courts have held that if the State laws in question differ substantially from each other, the cases do not present common issues sufficient to justify class treatment. See Wright, Miller and Kane, Federal Practice and Procedure (n 96) para 1782 ('The potential applicability of multiple State laws in actions seeking relief on behalf of a nationwide class may ... implicate the predominance requirement, leading to the denial of class certification').

104 See Empagran (n 36) 167 (recognising differences among national antitrust laws).

105 This element is discussed frequently in the securities context, where US law creates a presumption of reliance (through the fraud-on-the-market theory) that is not available to claims under foreign law. See Smith $v$ Dominion Bridge Corp 1998 WL 98998 (ED Pa 1998) (finding that the plaintiff had failed to establish typicality for this reason).

${ }^{106}$ While courts could establish sub-classes to address such conflicts, they typically decline to do so on grounds of manageability.

${ }_{107}$ Re DaimlerChrysler AG Securities Litigation 216 FRD 291 (D Del 2003).

108 That is, if there were no original diversity jurisdiction over their claims.

109 See discussion at n 64-65.
} 
question of class certification first. In that case, the court's focus might shift to the efficiencies of concentrating all claims based on the defendants' conduct in a single forum. ${ }^{110}$ Thus, although the certification requirements discussed above might yet militate against certification of a class including foreign claims, the likelihood of the court's adjudicating those claims along with US claims may be higher.

There is no fixed order in which courts must consider these questions, ${ }^{111}$ but in antitrust cases to date, courts have generally screened foreign claims on initial motions to dismiss ${ }^{112}$ rather than beginning with the certification question.

\section{Recognition of Foreign Judgments: The Question of Preclusion}

As noted above, US courts may obtain personal jurisdiction over non-resident class members by providing them with constructive notice and an opportunity to opt out. With respect to plaintiffs from other US States, a court is therefore assured that its disposition of the claims will be accorded preclusive effect - the constitutional guarantee that full faith and credit will be granted to the order of a court in a sister State means that such plaintiffs will not be able to relitigate in another US forum. With respect to foreign plaintiffs, however, no such assurance is possible; there is no guarantee that the courts in those plaintiffs' home countries will similarly grant preclusive effect. This situation creates an obstacle for foreign plaintiffs seeking to establish another element required for class certification: superiority.

Class certification is available only if the court concludes that a class action is superior to other methods of adjudication. But preclusive effect is critical to the viability of the group litigation mechanism; the class action defendant must be able to enter into a settlement, or proceed to judgment, with the assurance that members of the plaintiff class will not later be able to relitigate the claims in another forum. While countries differ in their approach to class action procedure, many object to the opt-out characteristic of the US system and might on that basis refuse to grant a US order preclusive effect. ${ }^{113}$ For that reason, a court considering certification of a multinational class might conclude that representative litigation was not superior to other methods of adjudication, at least with respect to the foreign claimants. In the area of securities litigation, US courts have taken this concern quite seriously, analysing the laws of putative class members' home jurisdictions and

\footnotetext{
${ }^{110}$ As part of the 'superiority' element of the certification analysis, Rule 23(b)(3)(C) invites the court to consider 'the desirability or undesirability of concentrating the litigation of the claims in the particular forum', which might lead to increased emphasis on global efficiency.

${ }^{111}$ In the analogous area of standing, courts differ on the proper order of inquiry. cp Re Chocolate Confectionary Antitrust Litigation 602 F Supp 2d 538, 579-80 (MD Pa 2009) ('the plaintiffs' capacity to represent individuals from other states depends on obtaining class certification, and the standing issue would not exist but for their assertion of [differing] state law antitrust claims ... Therefore, ... [the] class certification issues are "logically antecedent" to the standing concerns, and the court will defer ruling on the latter until class certification proceedings') and Re Potash Antitrust Litigation 667 F Supp 2d 907, 921-22 (ND Ill 2009) (rejecting such a general rule and holding that standing issues may be adjudicated prior to determining whether class certification requirements have been met).

112 See Re Hydrogen Peroxide Antitrust Litigation 552 F 3d 305 (3d Cir 2008).

113 For analysis, see A Pinna, 'Recognition and Res Judicata of US Class Action Judgments in European Legal Systems' (2008) 1 Erasmus Law Review 31; RA Nagareda, 'Aggregate Litigation Across the Atlantic and the Future of American Exceptionalism' (2009) 62 Vanderbilt Law Review 1 (analysing the relationship between scope of preclusion and scope of aggregation in the development of modern class actions); Wasserman, 'Transnational Class Actions' (n 91).
} 
making certification decisions accordingly. ${ }^{114}$ This trend suggests that the concentration of claims in US courts will remain limited as long as significant differences remain across legal systems in their procedural approach to group litigation.

\section{Conclusion}

In our view, the US experience provides several specific lessons and one general lesson for Europe.

1. A consistent focus on the affected market for questions of jurisdiction and applicable law is possible and yields consistent and acceptable results. It is problematic, however, where more than one market is affected.

2. Personal jurisdiction based on the place of the effects alone, as in Article 5(3) Brussels I Regulation, is problematic. A limitation based on intentional targeting seems desirable, though its exact contours, especially in the case of global cartels, are hard to define.

3. Where multiple defendants are involved, as in the case of a cartel, the domicile of one among them does not provide a sufficient basis for jurisdiction over the others. Therefore, Article 6(1) Brussels I Regulation requires at least the type of restrictive interpretation that Michael Wilderspin suggests in this volume. The US example suggests the possibility of going further by concentrating claims against multiple defendants in the most affected market, regardless of whether it is the domicile of any one of the defendants.

4. The law applicable to damages claims should follow, if at all possible, the law applicable to the antitrust violation itself.

5. The application of one law for damages arising in several countries, as envisaged in Article 6(3)(b) Rome II Regulation, is an interesting response to a problem that remains unresolved under US law.

6. A mechanism for aggregating claims from multiple jurisdictions implicates significant conflict-of-laws issues. The successful introduction of such a mechanism in Europe may require a base level of similarity in the procedural laws of the Member States.

\footnotetext{
114 See Re Alstom SA Securities Litigation 253 FRD 266 (SD NY 2008) (analysing the likelihood that its disposition of the case would be granted preclusive effect in France, England, the Netherlands and Canada); Vivendi Universal SA Securities Litigation 242 FRD 76, 95-105 (SD NY 2007) (Austria, England, France, Germany and the Netherlands).
} 